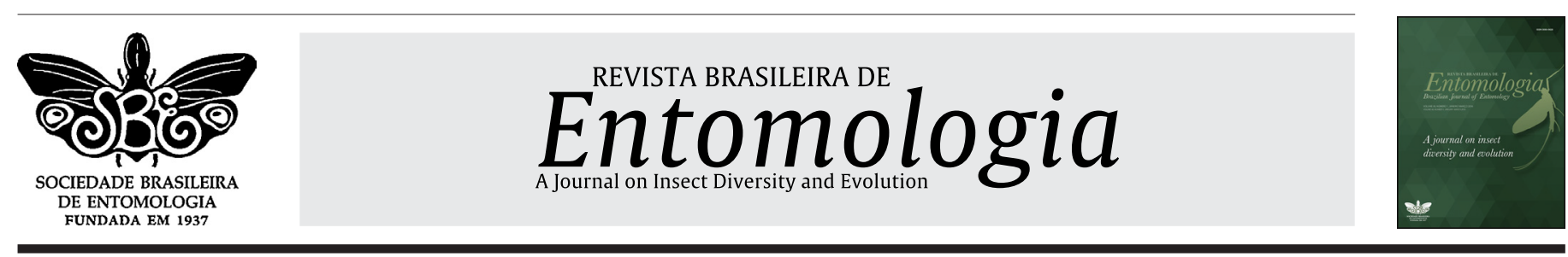

\title{
On the natural history of Cosmophyga cortesi Vargas (Lepidoptera: Geometridae), a little-known geometrid moth of the Atacama Desert
}

\author{
Héctor A. Vargas ${ }^{1 *}$ (1) \\ ${ }^{1}$ Universidad de Tarapacá, Facultad de Ciencias Agronómicas, Departamento de Recursos Ambientales, Arica, Chile.
}

\section{A R T I C L E I N F O}

Article history:

Received 13 April 2021

Accepted 13 June 2021

Available online 30 June 2021

Associate Editor: Thamara Zacca

\section{Keywords:}

Anacardiaceae

DNA barcoding

Folivorous larvae

Geometrid larvae

Potter wasps

\begin{abstract}
A B S T R A C T
The integration of field work with DNA barcoding is useful to disentangle lepidopteran interactions in nature. Adults of the little-known geometrid moth Cosmophyga cortesi Vargas, 2008 (Lepidoptera: Geometridae) were reared from folivorous larvae collected on the native tree Schinus areira L. (Anacardiaceae) at about 260 and 1500 m elevation in the transverse valleys of the Atacama Desert of northern Chile. Similarity of two DNA barcodes of C. cortesi was 99.7 and $100 \%$ with one sequence of an unidentified geometrid larva previously collected in a cell of the potter wasp Hypodynerus andeus (Packard, 1869) (Hymenoptera: Vespidae). This finding represents the first host plant record for $C$. cortesi, expands its previously documented altitudinal range by more than $1200 \mathrm{~m}$ and confirms that its larvae are captured by females of a potter wasp.
\end{abstract}

The transverse valleys of northern Chile harbor an important part of the biodiversity of the Atacama Desert, because their narrow perennial or semi-perennial water courses, which flow from the western slopes of the Andes range to the Pacific coast, enable the development of a wide range of organisms (Luebert and Pliscoff, 2006; Estades et al., 2007). Although with a low diversity of Lepidoptera, as expected for a hyperarid desert, these valleys harbor some species with narrow geographic ranges (Vargas-Ortiz et al., 2019) and represent the southern limit on the western margin of South America for some more widespread ones (Vargas, 2019; Davis et al., 2020). Unfortunately, the intensive agricultural activity in the transverse valleys has produced a remarkable modification of the natural habitats, with a drastic reduction of the area originally covered by natural vegetation and an uncontrolled increase of cultivated lands (Luebert and Pliscoff, 2006). All these changes represent serious threats for the biodiversity and could be especially harmful for phytophagous species that strongly depend on native plants for food (Estades et al., 2007), as is the case of some Lepidoptera with narrow host plant ranges. Knowledge of basic aspects of the natural history of each species inhabiting these valleys is needed to understand better their patterns of distribution and abundance.

\footnotetext{
* Corresponding author.

E-mail: lepvargas@gmail.com (H.A. Vargas).
}

The Geometridae (Lepidoptera) are a widely distributed family of moths, particularly diverse in the Neotropical Region (Brehm et al., 2019). Its main global diversity hotspot is found in the wet tropical Andes of southern Ecuador (Brehm et al., 2005, 2016), which contrasts sharply with the low species diversity of this family in the Atacama Desert (Rindge, 1987). The geometrid moths are mainly phytophagous (Scoble 1992). Geometrid larvae are dominant in caterpillar ensembles associated with some plants (Bodner et al., 2012), and are used as food substrate by a wide range of entomophagous insects (Osorio, 2005; Marconato et al., 2008; Geraldo, 2017) in the Neotropics. Host plant ranges from narrow to wide have been described for species inhabiting the west tropical Andes (Brehm, 2002, 2003; Bodner et al., 2010), while larvae of more than 20 species have been found associated with a single host plant in the Brazilian cerrado (Marconato et al., 2008). Although host plants are highly relevant in the life cycles of geometrid moths, the records remain incomplete for the species of the transverse valleys of the Atacama Desert (Méndez-Abarca et al., 2014), hindering the understanding of other interactions. Recent fieldwork enabled the discovery of the first host plant of the little-known geometrid moth Cosmophyga cortesiVargas, 2008, expanding its previously documented altitudinal range, and DNA barcodes confirmed the use of its larvae as prey by a potter wasp. 
One geometrid larva was collected on the native tree Schinus areira L. (Anacardiaceae), previously cited as Schinus molle L. in the study area (Rodriguez et al., 2018), using a beating sheet in the type locality of $C$. cortesi, at about 260 m elevation in the Azapa Valley ( $18^{\circ} 31^{\prime} 19^{\prime \prime} S$, $70^{\circ} 10^{\prime} 42$ 'W), in December, 2019. The collected larva was placed in a plastic vial with leaves of $S$. areira and paper towel at the bottom. Additional leaves were provided until the larva completed feeding and pupated. One female emerged in January 2020, about three weeks after pupation. It was mounted and its abdomen was removed and placed in hot $10 \% \mathrm{KOH}$ for a few minutes for genitalia dissection. The genitalia were stained with Eosin Y and Chlorazol Black and mounted on slides with Euparal. The specimen was identified as $C$. cortesibased on morphology (Vargas, 2008). No additional larvae of $C$. cortesi were found in three subsequent surveys in the same site between December 2019 and January 2020. A new survey (Figs. 1 and 2) was undertaken in November 2020 in the Livilcar Ravine (18 33'04"S, 69 45'53"W), at about $1500 \mathrm{~m}$ elevation in the same watershed as the type locality, following the methodology described above. The second site was selected because it is less human-modified than the type locality.
Three larvae of $C$. cortesi were collected, from which one female and two males were obtained in January 2021 (Fig. 3). Voucher specimens are deposited in the "Colección Entomológica de la Universidad de Tarapacá” (IDEA), Arica, Chile.

Genomic DNA was extracted from legs of one female and one male of the latter survey using the QIAamp® Fast DNA Tissue Kit, following the manufacturer's instructions, and sent to Macrogen Inc. (Seoul, South Korea) for purification, PCR amplification and sequencing of the barcode region (sensu Hebert et al., 2003) using the primers LCO1490 and HCO-2198 (Folmer et al., 1994). The fragments obtained were analyzed using the BOLD Identification System (Ratnasingham and Hebert, 2007).

Schinus areira is the first host plant recorded for $C$. cortesi. This finding highlights the importance of this native tree as a host of Lepidoptera native to the transverse valleys of the Atacama Desert (Pereira et al., 2017). More than 20 larvae of Iridopsis hausmanniVargas, 2007, another geometrid moth whose association with $S$. areira was already known (Vargas, 2014), were collected along with the larvae of $C$. cortesi. Although I. hausmanni outnumbered $C$. cortesi on this
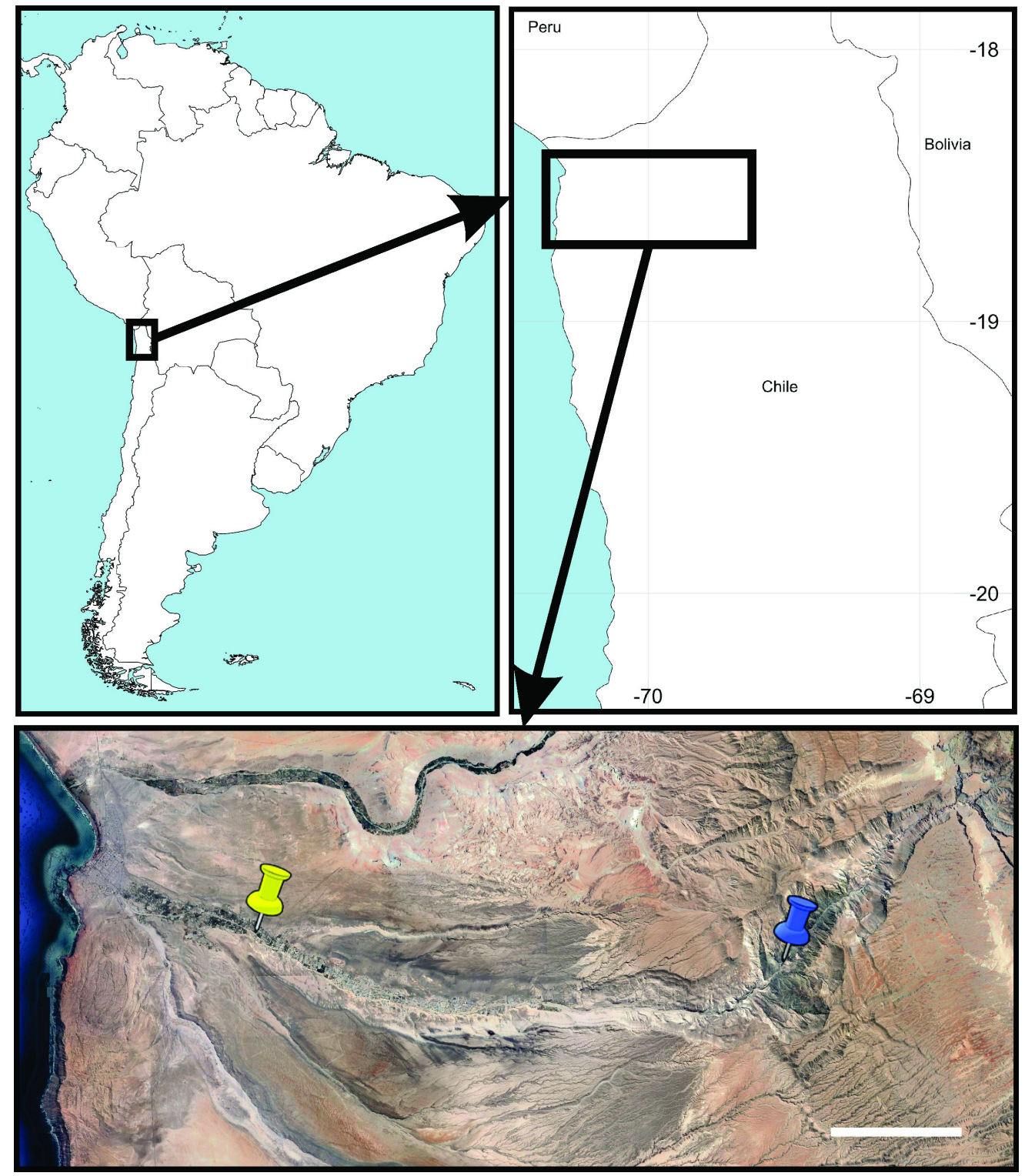

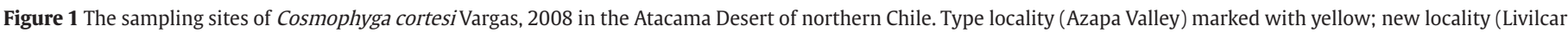
Ravine) marked with blue. Upper boxes generated with SimpleMappr (Shorthouse, 2010). Map data 2021 (C) Google for the lower box. Scale bar 10 km. 


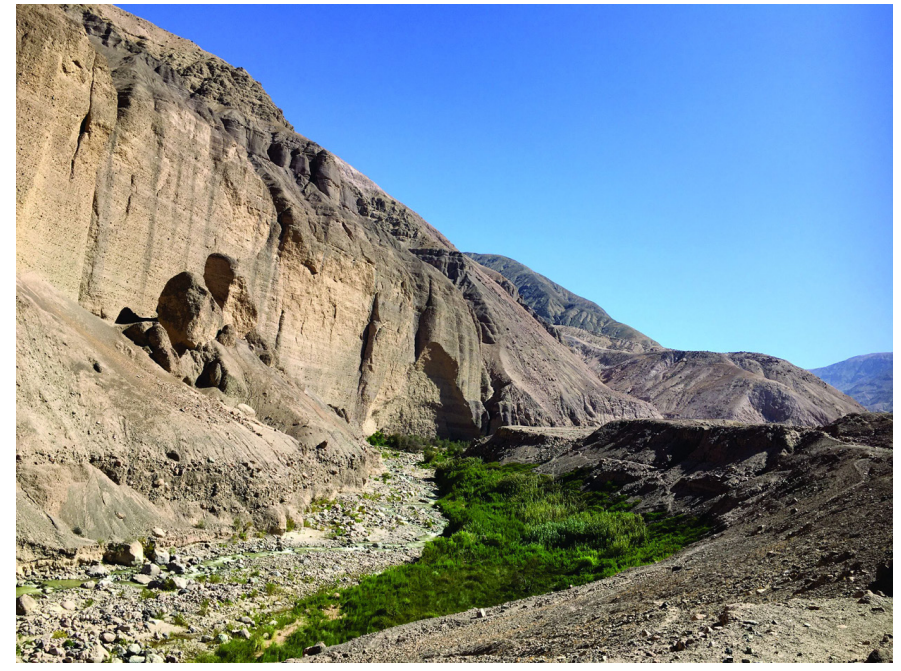

Figure 2 Habitat of Cosmophyga cortesi Vargas, 2008 in the Livilcar Ravine, Atacama Desert of northern Chile.

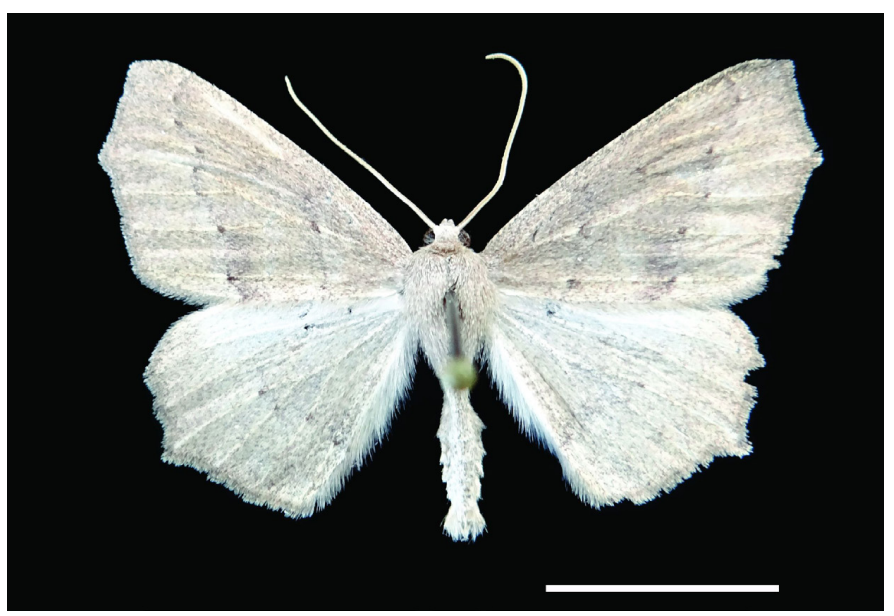

Figure 3 Male adult of Cosmophyga cortesi Vargas, 2008 reared from a folivorous larva collected on Schinus areira L. (Anacardiaceae) in the Livilcar Ravine, Atacama Desert of northern Chile. Scale bar $10 \mathrm{~mm}$.

occasion, further studies are needed to compare the abundance patterns of the two species more accurately.

As wide variation has been reported between the host ranges of different Neotropical geometrid moths (Brehm, 2002, 2003; Bocaz et al., 2003; Bodner et al., 2010; Seifert et al., 2015), other native shrubs and trees (mainly Asteraceae and Fabaceae) represented in the two study sites were surveyed for larvae of $C$. cortesi. No additional hosts of this moth were discovered in these surveys, suggesting that its host range is narrow. As $S$. areira is an evergreen tree (Rodríguez et al., 1983) and one of the more common native trees in the transverse valleys of the Atacama Desert (Gatica-Castro et al., 2015), folivorous species associated with it like the geometrid moths C. cortesi and I. hausmanni may find adequate substrate throughout the year. Accordingly, a narrow trophic association with leaves of $S$. areira could have been an advantage for the populations of these geometrid moths previous to the dramatic human modification of these valleys, but such a host specialization could represent a risk in the current scenario of habitat loss.

The only previous distribution record of $C$. cortesi was the type locality, at about 260 m elevation in the Azapa Valley (Vargas, 2008). Accordingly, the specimens collected in Livilcar, at about 1500 m elevation, expand the elevation range of $C$. cortesi by more than $1200 \mathrm{~m}$. Further sampling in additional valleys north and south of the type locality, is needed to characterize better the geographic range of $C$. cortesi.

In a previous study undertaken in the type locality of $C$. cortesi, Méndez-Abarca et al. (2012) reported that one male of this species, whose wings had not expanded more than 24 hours after emergence, was obtained from a full-grown larva found in a cell of the potter wasp Hypodynerus andeus (Packard, 1869) (Hymenoptera: Vespidae). As the host plant of $C$. cortesi was unknown at that time, it was not possible to associate the presence of the larva with any plant species in the study site. The host plant record here provided suggests that the larva was captured by a female of $H$. andeus on $S$. areira trees growing there. Furthermore, the similarity of the two DNA barcodes of C. cortesi (MW911318, MW911319) was 99.7 and 100\% with that of an unidentified larva of Geometridae (KF663055) collected in a cell of $H$. andeus in the type locality of $C$. cortesi (Vargas et al., 2014). This finding corroborates that larvae of $C$. cortesi are captured by females of $H$. andeus to fill their cells. Accordingly, availability of $S$. areira is important not only for the phytophagous $C$. cortesi, but also for the potter wasp $H$. andeus.

The integration of field work with DNA barcoding is useful to disentangle lepidopteran interactions in nature (Hausmann et al., 2020). In the present study, field work shed the first light on the host plant use by $C$. cortesi, while comparison of newly generated DNA barcodes with previously published ones confirmed the use of their larvae as prey. Further studies are needed to improve the understanding of the interactions of the geometrid moths inhabiting the transverse valleys of the Atacama Desert to begin to protect their populations and those of the native entomophagous associated with them in these dramatically human-modified landscapes.

\section{Acknowledgements}

I would like to thank Marcelo Vargas-Ortiz for the kind company in field work and for performing DNA extraction; Wilson Huanca-Mamani for allowing the use of the molecular biology equipment and Lafayette Eaton for checking the English.

\section{Conflicts of interest}

The author declares no conflicts of interest.

\section{References}

Bocaz, P., Parra, L. E., Victoriano, P. F., 2003. Larval morphological variation and its relation to host plants in Syncirsodes primata (Lepidoptera: geometridae). Gayana. 67, 39-44.

Bodner, F., Brehm, G., Homeier, J., Strutzenberger, P., Fiedler, K., 2010. Caterpillars and host plant records for 59 species of Geometridae (Lepidoptera) from a montane rainforest in southern Ecuador. J. Insect Sci. 10, 67. https://doi.org/10.1673/031.010.6701.

Bodner, F., Strutzenberger, P., Brehm, G., Fiedler, K., 2012. Species richness and host specificity among caterpillar ensembles on shrubs in the Andes of southern Ecuador. Neotrop. Entomol. 41, 375-385. https:// doi.org/10.1007/s13744-012-0066-4.

Brehm, G. 2002. Diversity of Geometrid Moths in a Montane Rainforest in Ecuador. PhD Thesis, University of Bayreuth, Bayreuth, Germany.

Brehm, G., 2003. Host-plant records and illustrations of the larvae of 19 geometrid moth species from a montane rain forest in Ecuador (Lepidoptera: geometridae). Nachr. Entomol. Ver. Apollo 24, 29-34. 
Brehm, G., Pitkin, L. M., Hilt, N., Fiedler, K., 2005. Montane Andean rain forests are a global diversity hotspot of geometrid moths. J. Biogeogr. 32, 1621-1627.

Brehm, G., Hebert, P. D. N., Colwell, R. K., Adams, M.-O., Bodner, F., Friedemann, K., Möckel, L., Fiedler, K., 2016. Turning up the heat on a hotspot: DNA barcodes reveal $80 \%$ more species of geometrid moths along an Andean elevational gradient. PLoS One 11 (3), e0150327. https://doi.org/10.1371/journal.pone.0150327.

Brehm, G., Murillo-Ramos, L., Sihvonen, P., Hausmann, A., Schmidt, B. C., Õunap, E., Moser, A., Mörtter, R., Bolt, D., Bodner, F., Lindt, A., Parra, L. E., Wahlberg, N., 2019. New World geometrid moths (Lepidoptera: Geometridae): Molecular phylogeny, biogeography, taxonomic updates and description of 11 new tribes. Arthropod Syst. Phylogeny 77, 457-486.

Davis, D. R., Farfán, J., Cerdeña, J., Huanca-Mamani, W., Vargas, H. A., Vargas-Ortiz, M., Gonçalves, G. L., Moreira, G. R. P., 2020. Adenogasteria leguminivora Davis \& Vargas gen. et sp. nov. (Lepidoptera: Gracillariidae): a new seed-feeding micromoth associated with Fabaceae in Peru and Chile. Austral Entomol. 59, 37-51. https:// doi.org/10.1111/aen.12439.

Estades, C. F., Aguirre, J., Escobar, M. A. H., Tomasevic, J. A., Vukasovic, M. A., Tala, C., 2007. Conservation status of the Chilean Woodstar Eulidia yarrellii. Bird Conserv. Int. 17, 163-175.

Folmer, O., Black, M., Hoeh, W., Lutz, R., Vrijenhoek, R., 1994. DNA primers for amplification of mitochondrial cytochrome c oxidase subunit I from diverse metazoan invertebrates. Mol. Mar. Biol. Biotechnol. 3, 294-299.

Gatica-Castro, A., Marticorena, A., Rojas, G., Arancio, G., Squeo, F. A., 2015. Estado de conservación de la flora nativa de las regiones de Arica-Parinacota y de Tarapacá, Chile. Gayana Bot. 72, 305-339. https://doi.org/10.4067/S0717-66432015000200013.

Geraldo, M. 2017. Geometridae (Lepidoptera) e Hymenoptera Parasitoides em Área de Mata Estacional Semidecídua na Estação Ecológica de Jataí, Luiz Antônio, SP. PhD Thesis, Universidade Federal de São Carlos, São Carlos, Brazil.

Hausmann, A., Diller, J., Moriniere, J., Höcherl, A., Floren, A., Haszprunar, G., 2020. DNA barcoding of fogged caterpillars in Peru: A novel approach for unveiling host-plant relationships of tropical moths (Insecta, Lepidoptera). PLoS One 15 (1), e0224188. https://doi. org/10.1371/journal.pone.0224188.

Hebert, P. D. N., Cywinska, A., Ball, S. L., deWaard, J. R., 2003. Biological identification through DNA barcodes. Proc. Biol. Sci. 270, 313-321. https://doi.org/10.1098/rspb.2002.2218.

Luebert, F., Pliscoff, P., 2006. Sinopsis Bioclimática y Vegetacional de Chile. Editorial Universitaria, Santiago.

Marconato, G., Dias, M. M., Penteado-Dias, M. A., 2008. Larvas de Geometridae (Lepidoptera) e seus parasitoides, associadas à Erythroxylum microphyllum St.-Hilaire (Erythroxylaceae). Rev. Bras. Entomol. 52, 296-299. https://doi.org/10.1590/S008556262008000200010.

Méndez-Abarca, F., Méndez, C. F., Mundaca, E. A., 2014. Host plant specificity of the moth species Glena mielkei (Lepidoptera, Geometridae) in northern Chile. Rev. Chil. Hist. Nat. 87, 22. https://doi.org/10.1186/ s40693-014-0022-2.
Méndez-Abarca, F., Mundaca, E. A., Vargas, H. A., 2012. First remarks on the nesting biology of Hypodynerus andeus (Packard) (Hymenoptera, Vespidae, Eumeninae) in the Azapa valley, northern Chile. Rev. Bras. Entomol. 56, 240-243. https://doi.org/10.1590/S008556262012005000033.

Osorio, T. C. 2005. Estágios Imaturos de Geometridae (Lepidoptera) Associados à Stryphnodendron spp. (Mimosaceae) em Área de Cerrado no Município de São Carlos, SP. Master Thesis, Universidade Federal de São Carlos, São Carlos, Brazil.

Pereira, C. M., Silva, D. S., Gonçalves, G. L., Vargas, H. A., Moreira, G. R. P., 2017. A new species of Leurocephala Davis \& Mc Kay (Lepidoptera, Gracillariidae) from the Azapa Valley, northern Chilean Atacama Desert, with notes on life-history. Rev. Bras. Entomol. 61, 6-15. https://doi.org/10.1016/j.rbe.2016.11.003.

Ratnasingham, S., Hebert, P. D. N., 2007. BOLD: the barcode of life data system (www.barcodinglife.org). Mol. Ecol. Notes 7, 355-367. https:// doi.org/10.1111/j.1471-8286.2007.01678.x.

Rindge, F. H., 1987. The Eupithecia of Chile (Lepidoptera, Geometridae). Bull. Am. Mus. Nat. Hist. 186, 269-363.

Rodríguez, R., Matthei, O., Quezada, M., 1983. Flora Arbórea de Chile. Editorial Universidad de Concepción, Concepción.

Rodriguez, R., Marticorena, C., Alarcón, D., Baeza, C., Cavieres, L., Finot, V. L., Fuentes, N., Kiessling, A., Mihoc, M., Pauchard, A., Ruiz, R., Sanchez, P., Marticorena, A., 2018. Catálogo de las plantas vasculares de Chile. Cayana Bot. 75, 1-430. https://doi.org/10.4067/S071766432018000100001.

Scoble, M. J. 1992. The Lepidoptera: Form, Function and Diversity. Oxford University Press, Oxford.

Seifert, C. L., Bodner, F., Brehm, G., Fiedler, K., 2015. Host plant associations and parasitism of south Ecuadorian Eois species (Lepidoptera: Geometridae) feeding on Peperomia (Piperaceae). J. Insect Sci. 15, 119. https://doi.org/10.1093/jisesa/iev098.

Shorthouse, D. P. 2010. SimpleMappr, an Online Tool to Produce PublicationQuality Point Maps. Available in: https://www.simplemappr.net (accessed 9 April 2021).

Vargas, H. A., 2008. Una nueva especie de Cosmophyga Dognin (Lepidoptera, Geometridae) del norte de Chile. Rev. Bras. Entomol. 52, 362-364.

Vargas, H. A., 2014. First host plant records for Iridopsis hausmanni Vargas (Lepidoptera, Geometridae) in the coastal valleys of northern Chile. Rev. Bras. Entomol. 58, 95-97. https://doi.org/10.1590/S008556262014000100015.

Vargas, H. A., 2019. Female genitalia of Pero obtusaria Prout, 1928 (Lepidoptera: geometridae). Rev. Bras. Entomol.63, 112-114. https:// doi.org/10.1016/j.rbe.2019.01.003.

Vargas, H. A., Vargas-Ortiz, M., Huanca-Mamani, W., Hausmann, A., 2014. Prey identification in nests of the potter wasp Hypodynerus andeus (Packard) (Hymenoptera, Vespidae, Eumeninae) using DNA barcodes. Rev. Bras. Entomol. 58, 157-160. https://doi.org/10.1590/ S0085-56262014000200007.

Vargas-Ortiz, M., Gonçalves, G. L., Huanca-Mamani, W., Vargas, H. A., Moreira, G. R. P., 2019. Description, natural history and genetic variation of Caloptilia guacanivora sp. nov. Vargas-Ortiz \& Vargas (Lepidoptera: Gracillariidae) in the Atacama Desert, Chile. Austral Entomol. 58, 171-191. https://doi.org/10.1111/aen.12351. 